\section{ODONATA OF KEOLADEO NATIONAL PARK, BHARATHPUR, RAJASTHAN, INDIA}

\author{
Muhamed Jafer Palot and V.P. Soniya
}

Zoological Survey of India, Freshwater Biological Station, 1-1-300/B Ashok Nagar, Hyderabad, Andhra Pradesh 500020, India.

Dragonflies and Damselflies (Insecta: Odonata) are perhaps the most fascinating insects of freshwater habitats. Fraser (193336) dealt in detail with the Odonate fauna of India, including some species from Rajasthan. Agrawal (1957) recorded 15 species from Pilani, northern Rajasthan. While, Bose and Mitra (1975) reported 13 species from the state, Prasad and Thakur (1981) listed 16 species from Rajasthan. Thakur (1985) reported 18 species of Odonates from the lake Kailana, Jodhpur. However, there appears to be no study on Odonata fauna of the Keoladeo National Park, Bharathpur. Hence an attempt has been made to study the same during our seasonal hydrobiological surveys to the Park from 13 April 1999 to 24 April 1999 (Summer survey) and 1 December 1999 to 5 December 1999 (Winter survey).

The Keoladeo National Park is situated in the Indo-Gangetic flood plains between longitude $77^{\circ} 29^{\prime} 5^{\prime \prime}$ to $77^{\circ} 33^{\prime} 9^{\prime \prime}$ E. and latitude $27^{0} 7^{\prime} 6^{\prime \prime}$ to $27^{\circ} 12^{\prime} 2^{\prime \prime} \mathrm{N}$ in the Bharathpur District of Rajasthan. It is a man-made wetland. The Park covers 29 sq.km. out of which 12 sq. km. forms the wetland zone. It is flat with a gentle slope towards the centre, forming a depression of about 8.5 sq.km., which is the submersible area of the Park, providing shelter to the water fowls and other aquatic animals. Water level varies from 0 to $2 \mathrm{~m}$. The area receives water from River Gambhir, a tributary of River Yamuna. The Park experiences extreme climatic conditions. Temperature varies from $2^{\circ} \mathrm{C}$ in winter (Nov-Feb) to $49^{\circ} \mathrm{C}$ in summer (Mar-Jun). The average annual rainfall is 662 mm. mostly from the South-west Monsoon during July to September. Due to varying eco-climatic conditions, the general vegetation of the Park is remarkable, comprising of 379 species of plants, which include 96 species of wetland plants (Meena \& Sharma, 1996).

Altogether, 16 species of odonates belonging to two families, eight subfamilies, and 14 genera were recorded during the study. Sub order Zygoptera (damselflies) is represented by the family Coenagrionidae with five species where as Anisoptera (dragonflies) by family Libellulidae of 11 species. All the 16 species are new reports from the Keoladeo National Park, as well as new distributional records from the state. Five taxa, Ceriagrion coromandelianum (Fabr.), Pseudagrion decorum (Ramb.), Ischnura delicata (Ramb), Diplacoides trivialis Ramb. and Rhyothemis variegata variegata Linn. are reported for the first time from Rajasthan (Mitra, 1999).

The Summer survey showed a total of 10 species (1 Damselfly and 9 Dragonflies) and winter survey with 12 species (5 Damselflies and 7 Dragonflies). Species such as Ceriagrion coromandelianum, Orthetrum sabina, Acisoma panorpoides, Crocothemis servilia, Diplacoides lefbvrei and Diplacoides trivialis were present during both survey periods.

Brachydiplax sobrina, Brachythemis contaminata and Rhyothemis vareigata were observed only in summer where as Psuedagrion decorum, Ischnura delicata, I. senegalensis, Bradinopyga geminata and Tramea basilaris occured in winter. In Summer survey, Crocothemis servilia is the most abundant species in the Park followed by Orthetrum sabina and Diplacoides trivialis. While in winter, Agriocnemis pygmae is the most extensively distributed species in the area. A detailed systematic list along with their seasonal occurrence is given in Table 1. The classification and nomenclature is adapted after Fraser (1957) and, Prasad and Varshney (1995).

\section{$\underline{\text { Systematic Account }}$}

\author{
Order: Odonata \\ Suborder: Zygoptera \\ Super family: Coenagrionoidea \\ Family: Coenagrionidae \\ Sub family: Pseudagrioniae
}

\section{Ceriagrion coromandelianum (Fabr.)}

Material examined: 2 males and 1 female, 21.iv.1999, Kraunch Sagar; 3 males, 2.xii.1999, Rambund; 2 males and 1 female, 3.xii.1999, Keoladeo Temple; 1 male, 5.xii.1999, Jaltoli Canal; 1 male, 5.xii.1999, Koladahr.

Remarks: Abundant and widely distributed throughout wetlands in summer as well as in winter.

\section{Pseudagrion decorum (Ramb.)}

Material examined: 2 males, 3.xii.1999, Keoladeo Temple; 1 female, 2.xii.1999, Rambund.

Remarks: Males common at lake in front of Keoladeo Temple in winter among littoral vegetation. Female collected from Hygrophila auriculata thickets at Rambund.

Sub Family: Ischnurinae

\section{Ischnura delicata Hagen.}

Material examined: 1 male, 5.xii.1999, Jaltoli.

Remarks: Rare. Only a single specimen observed in winter among Hygrophila bushes.

\section{Ischnura senegalensis Rambur.}

Material examined: 3 males, 5.xii.1999, Keoladeo Temple; 1 male, 5.xii.1999, Sampanmari; 1 male, 5.xii.1999, Koladahar.

Remarks: Common at lake in front of Keoladeo Temple among 
littoral vegetation, along with Pseudagrion decorum, Agriocnemis pygmaea and Ceriagrion coromandelianum in winter. Rare at Sampanmari and Koladahr.

\section{Agriocnemis oygmae (Ramb.)}

Subfamily: Agriocnemidinae

Material examined: 8 males, 2.xii.1999, Rambund; 1 male, 3.xii.1999, Keoladeo Temple; 1 male, 4.xii.1999, Python Point; 4 males and 5 females, 5.xii.1999, Koladahr.

Remarks: Most abundant species, found extensively distributed throughout the wetlands in winter. They remain perched mainly on Hygrophila auriculata heterochrome females were most common at Koladahr. Random sweeping of Hygrophila auriculata bushes during evening hours indicated it as a roosting place.

Sub Order: Anisoptera

Super Family: Libelluloidae

Family: Libellulidae

Sub Family: Brachydiplactinae

\section{Brachydiplax sobrina (Ramb.)}

Material examined: 1 male and 2 females, 22.iv.1999, Keoladeo Temple.

Remarks: Common in summer throughout the wetlands at Rambund Sampanmari and Keoladeo Temple area. Both male and female found resting on twigs and shrubs near the wetland.

\section{Orthetrum sabina sabina (Drury)}

\section{Subfamily: Libellulinae}

Material examined: 1 male, 21.iv.1999, Rambund; 1 male, 21.iv.1999, Kraunch Sagar; 1 male and 1 female, 2.xii.1999, Kraunch Sagar; 1 male and 1 female, 3.xii.1999, Mansarovar.

Remarks: Common throughout the Park in summer, less common in winter. Observed in tandem and wheel positions in April. Mostly found perched on bare twigs projecting out of water or on dry grasses.

\section{Subfamily: Sympetrinae}

\section{Acisoma panorpoides panorpoides Ramb.}

Material examined: 2 females, 21.iv.1999, Sampanmari; 1 male, 21.iv.1999, Sampanmari; 1 male, 3.xii.1999, Sampanmari.

Remarks: Very common near wetlands at Sampanmari and Keoladeo Temple in summer. Rare in winter. One male collected from Polygonum glabrum plant near Sampanmari and one female sighted on the way to Kadamkunj in winter.

\section{Brachythemis contaminata (Fabr.)}

Material examined: 1 male and 3 females, 22.iv.1999, Koeladeo Temple.

Remarks: Very common in summer among littoral vegetation at Keoladeo Temple lake.

\section{Bradinopyga geminata (Ramb.)}

Material examined: 1 male, 5.xii.1999, Koladhar.

Remarks: Rare. Observed near a cemented tank at Koladahar chowki.

\section{Crocothemis servilia servilia (Drury)}

Material examined: 1 female and 1 male, 21.iv.1999, Rambund; 1 male, 22.iv.1999, Keoladeo Temple; 1 female and 1 male, 22.iv.1999, Sampanmari; 2 females, 21.iv.1999, Nauka Vihar; 2 males and 1 female, 19.iv.1999, Santikutir; 1 female, 22.iv.1999, Python point; 1 male and 1 female 4.xii.1999, Kadamkunj; 1 male and 1 female, 3.xii.1999, Sampanmari; 1 female and 1 male, 5.xii.1999, Koladahar; 2 females, 3.xii.1999, Sampanmari.

Remarks: Very common during both survey periods. Extensively distributed throughout the Park. A small population found roosting on Hygrophila auriculata bushes at Shantikutir in early morning hours. The left hindwing of a male and a female showed variation and assymetry in wing venation. The discoidal cell of left hindwing traversed once in both the specimens, the right being entire.

\section{Deplacoides lefbvrei (Ramb.)}

Material examined: 2 males, 22.iv.1999, Sampanmari; 1 male, 2.xii.1999, Rambund.

Remarks: Very common near wetlands in April, distributed throughout the Park in December. Found perched on trek paths and open areas.

\section{Diplacoides trivialis (Ramb.)}

Material examined: 1 female, 21.iv.1999, Rambund; 1 male, 21.iv.1999, Kraunch Sagar; 1 female, 2.xii.1999, Kraunch Sagar; 2 females, 5.xii.1999, Koladahar.

Remarks: Common throughout the Park during summer and winter. Found on trek paths and open areas.

\section{Subfamily: Trithemistinae}

14. Trithemis pallidinervis Kirby.

Material examined: 2 females, 21.iv.1999, Rambund.

Remarks: Rare

\section{Subfamily: Trameinae}

\section{Rhyothemis variegata variegata Linn.}

Material examined: 1 female, 21.iv.1999, Rambund.

Remarks: Rare. Only a single specimen collected from Rambund in summer.

\section{Tramea basilaris burmeisteri Kirby.} Material examined: 1 male, 5.xii.1999, Koladahar. Remarks: Rare. Only recorded in the drier parts of Koladahar and Bahnera area towards Chicksana Canal during winter. 


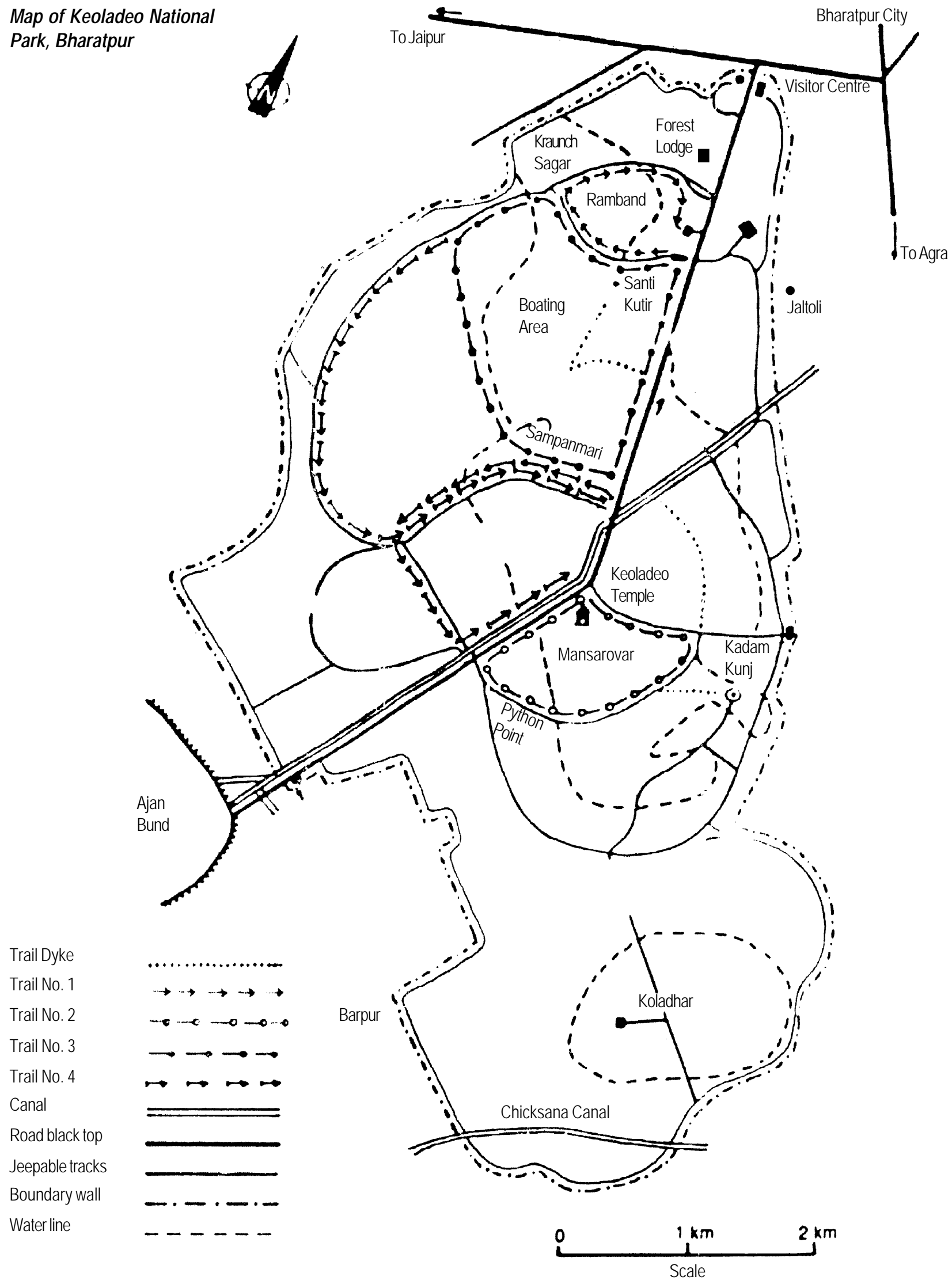


Table 1. Species List Showing Seasonal Occurrence.

\begin{tabular}{lcc}
\hline Species & Summer & Winter \\
\hline 1. Ceriagrion coromandelianum (Fabr.) & + & + \\
2. Pseudagrion decorum (Ramb.) & - & + \\
3. Ischnura delicata Hagen. & - & + \\
4. Ischnura senegalensis (Ramb.) & - & + \\
5. Agriocnemis pygmae (Ramb.) & - & + \\
6. Brachydiplax sobrina (Ramb.) & + & - \\
7. Orthetrum sabina sabina (Drury) & + & + \\
8. Acisoma panorpoides panorpoides (Ramb.) & + & + \\
9. Brachythemis contaminata (Fabr.) & + & + \\
10. Bradinopyga geminata (Ramb.) & - & + \\
11. Crocothemis servilia servilia (Drury). & + & + \\
12. Diplacoides lefbvrei (Ramb.) & + & - \\
13. Diplacoides trivialis (Ramb.) & + & - \\
14. Trithemis pallidinervis Kirby. & + & + \\
15. Rhyothemis variegata variegata Linn. & + & + \\
16. Tramea basilaris burmeisteri Kirby. & - & \\
\hline
\end{tabular}

\section{Acknowledgements}

The authors are greatful to Director, Zoological Survey of India and Officer-in-Charge, Zoological Survey of India, Freshwater Biological Station for various facilities. Thanks are also due to Dr. S.Z. Siddiqi and Sri S.S. Kamble, the leaders of the survey parties and Mrs. Shruthi Sharma, Deputy Conservator of Forests, Keoladeo National Park, Bharatpur for the help rendered to undertake the survey.

\section{References}

Agrawal, J.P. (1957). Contributions towards the Odonata fauna of Pilani. Proc. $44^{\text {th }}$ Ind. Sci. Cong. Calcutta. Part 3. Abstract no. 28: 309. Bose, G. and T.R. Mitra (1975). The Odonata fauna of Rajasthan. Rec. Zool. Surv. India 71: 1-11.

Fraser, F.C. (1933-36). Fauna of British India including Ceylon and Burma. Odonata Vol.1-3. Taylor \& Francis, London.

Fraser, F.C. 1957. A re-classification of order Odonata. R. Soc. N.S.W. Hand Book \# 12.

Meena, B.L. and S. Sharma (1996). Keoladeo National Park, Bharatpur, Rajasthan. Forest Department, Rajasthan.

Mitra, T.R. (1999). Geographical diatribution and zoogeography of Odonata (Insecta) of Meghalaya, India. Rec. Zool. Surv. India. Occ.pap. 170: 1-63.

Prasad, M. and R.K. Thakur (1981). Further additions to the Odonata fauna of Rajasthan. Jantu 1: 26-29.

Prasad, M. and R.K. Varshney (1995). Odonate fauna of India. Oriental Insects 29: 385-428.

Thakur, B.K. (1985). Field notes on the Odonata around lake Kailana, Jodhpur (Rajasthan). Bull. Zool. Surv. India. 7(1): 143-149. 